\title{
Ahmadu Bello University: Department of Languages
}

Ahmadu Bello Unrversity in Zaria, Northern Nigeria, is to open a new Department of Languages at the beginning of this session. It will concentrate primarily on French at the undergraduate level and post-graduate studies in Hausa for the first year or so, after which it is hoped to start an undergraduate course in Hausa. The Head of the Department is Mr. A. H. M. Kirk-Greene, a former Administrative Officer and Reader in Public Administration at the University. Mr. Kirk-Greene is at present working on a Hausa grammar in collaboration with Professor Kraft of Michigan State University and on a modern Hausa Reader with Malam Yahaya Aliyu of the Northern Secondary Teachers' College.

\section{Michigan State University: African Studies Center}

THe African Studies Center of Michigan State University, in co-operation with the Department of Oriental and African Languages and Linguistics, has planned an expanded African languages programme for 1964-5. Courses at introductory level will be given in Bemba, Igbo, Swahili, and West African Pidgin English, while those in Hausa and Yoruba will provide for introductory, intermediate, and advanced levels. The Center, in conjunction with other departments, also offers a wide variety of non-language courses dealing with Africa in anthropology, economics, education, geography, history, political science, and sociology. Further information may be obtained from Dr. Charles C. Hughes, Director, African Studies Center, Michigan State University.

\section{'A History of the Gold Coast and Ashanti'; 'Igbo Village Affairs'}

$A$ History of the Gold Coast and Ashanti, by W. Walton Claridge, first published in I9I 5 , has now been reprinted (London: Frank Cass, 1964. Two volumes, $f_{8.85}$.). An introduction to the second edition has been written by W. E. F. Ward, author of $A$ History of Ghana, who discusses Claridge's work in the light of recent research.

The same publisher has brought out a second edition of M. M. Green's Igbo Village Affairs (35s.), which refers mainly to the village of Umueke Agbaja. In her new preface Miss Green comments on changes which have occurred since the book's first publication in 1947.

\section{Republication of S. W. Koelle's 'Polyglotta Africana'}

Support for the republication of the Polyglotta Africana was expressed in a resolution by the Third West African Languages Congress, held in March 1963 at Fourah Bay College, the University College of Sierra Leone. This work, compiled while Koelle was a tutor at Fourah Bay, was first published in 1854 , and a special reprint has now been published in association with the Sierra Leone Language Review, the African Language Journal of Fourah Bay College. This reprint has been financed by means of a generous grant from the Deutsche Forschungsgemeinschaft, and copies are being distributed free of charge to individual scholars of African languages: copies of the Fourah Bay reprint are not available for sale, but copies of a simultaneous commercial reprint may be purchased from the Akademische Druckund Verlagsanstalt (Graz, Austria). Both reprints include an historical introduction by Dr. P. E. H. Hair, recently Lecturer in History at Fourah Bay College.

It is intended that the wider availability of the Polyglotta should serve to encourage and facilitate further detailed comparative work in the African field, including the compilation of a linguistic and historical Symposium on the Polyglotta itself. Papers intended for this Symposium are to be published initially in the Sierra Leone Language Review, and the first four of these papers are included in the current number (No. 3/1964). 